\title{
KAJIAN KELAYAKAN PENERAPAN KONSEP BADAN LAYANAN UMUM DAERAH (BLUD) PADA BADAN PENGEMBANGAN SUMBER DAYA MANUSIA DAERAH PROVINSI KALIMANTAN SELATAN
}

\section{FEASIBILITY STUDY OF BLUD CONCEPT IMPLEMENTATION IN REGIONAL HUMAN RESOURCES DEVELOPMENT AGENCIES OF SOUTH KALIMANTAN PROVINCE}

\author{
Sugiyono \\ Badan Pengembangan Sumber Daya Manusia Daerah Provinsi Kalimantan Selatan \\ Jalan Penglima Batur Timur Nomor 1A, Banjarbaru, Kalimantan Selatan, Indonesia \\ email: oegie.jwr@gmail.com
}

Diserahkan: 23/03/2021, Diperbaiki : 05/05/2021, Disetujui : 10/02/2021

DOI: $10.47441 / \mathrm{jkp} . v 16 i 1.151$

\begin{abstract}
Abstrak
Badan Pengembangan Sumber Daya Manusia Daerah (BPSDMD) Provinsi Kalimantan Selatan memiliki peran strategis dalam menyediakan program pelatihan yang inovatif untuk pengembangan kompetensi Aparatur Sipil Negara (ASN). Akan tetapi, pengembangan program tersebut dihadapkan pada permasalahan terbatasnya anggaran dan proses penyediaan dana yang tidak efisien. Kondisi ini disebabkan oleh sistem pengelolaan keuangan yang belum mandiri dan fleksibel. Permendagri 79 Tahun 2018 memberikan peluang perbaikan sistem pengelolaan keuangan melalui penerapan konsep pengelolaan keuangan Badan Layanan Umum Daerah (PPK-BLUD). Kajian ini bertujuan untuk menilai kelayakan penerapan konsep BLUD. Metode yang digunakan adalah deskriptif dengan pendekatan kualitatif. Hasil kajian menunjukan bahwa BPSDMD Provinsi Kalimantan Selatan dinilai dapat memenuhi persyaratan substantif, teknis dan administratif untuk pembentukan BLUD.
\end{abstract}

Kata Kunci : BPSDMD, BLUD, Pengelolaan Keuangan

\begin{abstract}
The Regional Human Resources Development Agency (BPSDMD) of South Kalimantan Province has a strategic role in providing innovative training programs for competency development of the State Civil Service (ASN). However, the development of this program was faced with the problem of limited budget and inefficient process of providing funds. This condition is caused by a financial management system that is not yet independent and flexible. Regulation of Ministry of Home Affairs of the Republic of Indonesia Number 79/ 2018 provides opportunities to improve the financial management system through the application of the financial management concept of Regional Public Service Bodies (PPK$B L U D)$. This study aims to assess the feasibility of implementing the BLUD concept. The method used is descriptive with a qualitative approach. The results of the study show that the BPSDMD of South Kalimantan Province is considered to be able to meet the substantive, technical and administrative requirements for the formation of a BLUD.
\end{abstract}

Keywords: BPSDMD, BLUD, Financial Management 


\section{PENDAHULUAN}

Pengembangan kompetensi sumber daya manusia (SDM) merupakan hal yang penting untuk dilakukan, hal ini sejalan dengan pemikiran Draft (2012) bahwa modal manusia (human capital) merupakan nilai ekonomis dari perpaduan antara pengetahuan, pengalaman, keterampilan dan kemampuan para pegawai. Oleh karena itu, manajemen SDM perlu mengembangkan strategi-strategi untuk mencari orang-orang terbaik, meningkatkan keterampilan dan pengetahuan mereka dengan memberikan program pelatihan dan peluang bagi pengembangan diri dan professional.

Lembaga-lembaga pelatihan memiliki peran strategis dalam pengembangan kompetensi aparatur pemerintah. BPSDMD Provinsi Kalimantan Selatan dalam konteks pengembangan aparatur lingkup pemerintah daerah memiliki peran strategis yang sesuai dengan kewenangannya dalam upaya mewujudkan tata kelola pemerintahan profesional dan berorientasi pada pelayanan publik. Peran tersebut meliputi, pemenuhan kompetensi SDM pengelola pelatihan/fasilitator dalam penguasaan teknologi informasi, ketersediaan akses dan infrastruktur pelatihan, kesiapan bahan dan kurikulum pelatihan. Aspek penting efektifitas capaian sasarang menyangkut dukungan anggaran .

Program dan kegiatan pelatihan aparatur di BPSDMD Provinsi Kalimantan Selatan sepenuhnya dibiayai dari APBD Provinsi Kalimantan Selatan. Sebagai gambaran berdasarkan alokasi Tahun Anggaran 2018 sebesar Rp8.772.602 dan Tahun Anggaran 2019 sebesar Rp1.200.314.010, terdapat penurunan sebesar 8,25 persen. TA 2018 menghasilkan 1.299 orang PNS kompeten melalui 18 jenis pelatihan, sedangkan TA 2019 sebanyak 2.850 PNS kompeten melalui 16 jenis pelatihan (Lakip BPSDMD, 2018 \& 2019). Berdasarkan gambaran tersebut, dengan jumlah PNS lingkup Pemerintah Provinsi Kalimantan Selatan kurang lebih 10.000 orang, rata-rata PNS yang mendapatkan kesempatan peningkatan kompetensi melalui pelatihan hanya sebesar 20 persen dan dinilai belum optimal.

Terbatasnya anggaran masih menjadi persoalan BPSDMD dalam peningkatan kompetensi aparatur. Hal tersebut berimplikasi pada perencanaan program pelatihan yang monoton tiap tahunnya, dan kesulitan dalam mengembangkan program pelatihan yang inovatif dan berskala nasional. Kondisi ini berdampak bagi stakeholder eksternal di 13 pemerintah kabupaten/kota, serta instansi lainnya yang tidak bisa melakukan kerjasama pelatihan di BPSDM Kalsel, sehingga mereka harus melakukan pengiriman peserta pelatihan keluar Provinsi Kalimantan Selatan.

Selain keterbatasan anggaran pelatihan, sistem pengelolaan keuangan yang diterapkan saat ini dinilai kaku dan tidak fleksibel, serta dan proses/alur penyediaan dana cukup panjang. Keluhan peserta pelatihan menyangkut sarana dan prasarana pelatihan tidak dapat segera diatasi karena dana tidak tersedia dan perlu proses penyiapan. Oleh karena itu, permasalahan keterbatasan anggaran dan sistem pengelolaan keuangan perlu menjadi fokus dalam melakukan perubahan untuk peningkatan kualitas penyelenggaraan pelatihan.

Penerapan BLUD yang mandiri dan fleksibel merupakan peluang lembaga pelatihan untuk mengembangkan program dan kegiatan inovatif dan variatif dengan cakupan luas. Keterbatasan anggaran dapat diatasi dengan sumber-sumber pendanaan lain yang sah selain APBD provinsi, dimana pengelolaannya dapat dilakukan secara mandiri. Menurut Lukman (2013) bahwa dengan transformasi BLUD yang dijalankan seperti entitas bisnis (businesslike) yang menganut manajemen dan praktik bisnis ala korporat, stigma negatif instansi yang boros dan lambat dapat dihilangkan. Permasalahan pembentukan BLUD dihadapkan pada kekhawatiran bahwa perubahan sistem akan menghambat aktifitas pengelolaan keuangan yang selama ini telah di jalankan, dan kesiapan perubahan mind set aparatur dengan semangat kewirausahaan. Trianasari dan Idrus (2011), menilai bahwa penerapan BLUD telah mempengaruhi kondisi dan kinerja organisasi. Penerapan BLUD, menurut Fahmi (2014) perlu persiapan berupa kajian kelayakan, yang hasilnya dapat menjadi rujukan proses pembentukan selanjutnya. 
Konsep BLU/BLUD merupakan amanat Undang-Undang Nomor 1 Tahun 2004 tentang Perbendaharaan Negara, Undang-Undang Nomor 23 Tahun 2005 tentang Pengelolaan Keuangan BLU serta peraturan-peraturan turunan yang mengatur secara teknis terkait BLU/BLUD. Dalam manajemen ataupun administrasi publik, ada 2 hal pokok yang bisa di hubungkan literatur administrasi publik dengan konsep BLU/BLUD. Pertama adalah terminologi yang disebut manajemen publik baru (New Public Management/NPM), kedua adalah pengagenan/agensifikasi (agensification). Konsep mewirausahakan birokrasi sebagaimana gagasan Osborne dan Gaebler (1992) menjadi cara yang efisien untuk menghindari kebangkrutan suatu birokrasi. Mewirausahaan birokrasi (reinventing government) merupakan sebuah konsep tentang cara birokrasi mengubah sistem atau pengaturan agar pelaksanaan proses pemerintahan dapat berjalan secara akuntabilitas, responsif, inovatif, professional, dan entrepreneur. Konsep yang dikemukakan Osborne dan Gaebler dinilai relevan untuk melakukan reformasi bidang keuangan, yaitu perubahan pengelolaan keuangan yang lebih fleksibel melalui BLUD untuk peningkatan pelayanan publik.

Kualitas pelayanan publik sangat tergantung bagaimana organisasi merespon kebutuhan dan tuntutan pelanggan. Lembaga Administrasi Negara (1998) memberikan pemahaman pelayanan publik sebagai segala bentuk kegiatan pelayanan umum dilaksanakan instansi pemerintah di pusat dan daerah, dan di lingkungan BUMN/BUMD dalam bentuk barang dan/atau jasa, dalam pemenuhan kebutuhan masyarakat. Organisasi yang adaptif merupakan salah satu unsur penting perbaikan kualitas layanan. Sejalan dengan konsep di atas perbaikan sistem melalui BLUD merupakan salah satu cara peningkatan kualitas pelayanan publik.

Konsep Badan Layanan Umum Daerah bertujuan memberikan layanan umum lebih efektif, terjadi efisiensi, ekonomis, terbuka/transparan dan bertanggung jawab dengan memperhatikan asas kepatutan, keadilan dan manfaat sesuai dengan praktek bisnis sehat. Hasil kajian Pandriadi (2017) mengenai implementasi BLUD menunjukkan dapat memperbaiki tata kelola hutan dengan menggunakan konsep transparan, akuntabel dan partisipatif. Hal ini sejalan dengan tujuan pembentukan BLUD dalam peningkatan kualitas pelayanan.

Berdasarkan permasalahan keterbatasan anggaran di lembaga pelatihan, peluang pengelolaan keuangan yang mandiri dan fleksibel perlu dikaji mendalam kelayakannya. Kajian merupakan tahap penting sebelum penerapan sebuah konsep baru. Hasil kajian dapat menjadi rujukan dalam menyusun strategi penerapan konsep BLUD di BPSDMD Provinsi Kalimantan Selatan.

\section{METODE PENELITIAN}

Penelitian ini dilaksanakan selama 6 (enam) bulan dari Maret s.d Agustus 2020 dengan lokasi kajian di BPSDMD Provinsi Kalimantan Selatan. Ruang lingkup kajian mencakup 2 hal, yaitu pertama, deskripsi pra kondisi lembaga pelatihan, dan kedua, gambaran pemenuhan persyaratan penerapan BLUD berdasarkan Permendagri 79 Tahun 2018. Penelitian menggunakan pendekatan kualitatif dengan metode deskriptif. Indikator merujuk persyaratan formal pembentukan BLUD meliputi persyaratan substantif, teknis dan administratif (Permendagri 79 Tahun 2018). Pengambilan sampel melalui metode purposive sampling dengan teknik pengumpulan data melalui wawancara mendalam (in depth interview) menggunakan pedoman wawancara, studi literatur dan dokumentasi. Unit analisis sebanyak 13 informan dari 9 instansi lingkup Pemerintah Provinsi Kalimantan Selatan, 3 instansi luar Provinsi Kalimantan Selatan dan 1 dari Sub Direktorat BLUD Direktorat Jenderal Keuangan Daerah Kementrian Dalam Negeri RI. Teknik analisis data) mencakup reduksi data (data reduction), penyajian data (data display), dan kesimpulan atau verifikasi (conclusion drawing) Miles dan Huberman (2005). 


\section{HASIL DAN PEMBAHASAN}

\section{Pra Kondisi Badan Pengembangan Sumber Daya Manusia Daerah Provinsi Kalimantan Selatan}

Peraturan Gubernur Nomor 0137 Tahun 2017 tentang Tugas Pokok, Fungsi BPSDMD Provinsi Kalimantan Selatan menegaskan bahwa tugas utamanya adalah melaksanakan fungsi penunjang urusan pemerintahan yang menjadi kewenangan daerah di bidang pengembangan sumber daya manusia daerah. Salah satu komitmen dalam rencana strategis adalah mewujudkan penerapan BLUD di BPSDMD Provinsi Kalimantan Selatan. Kajian kelayakan merupakan sebuah langkah strategis percepatan perubahan sistem pengelolaan keuangan.

Efektifitas penerapan sistem baru sangat tergantung pada pra kondisi organisasi. Lingkungan organisasi merupakan aspek penting sebagaimana pendapat Robbins (2006) bahwa lingkungan organisasi adalah lembaga-lembaga atau kekuatan-kekuatan yang berada di luar organisasi dan secara potensial mempengaruhi kinerja organisasi. Lingkungan dapat menjadi faktor pendukung maupun penghambat organisasi. Begitu pula halnya penerapan sistem BLUD di BPSDMD Provinsi Kalsel perlu diketahui pra kondisi yang mendukung penerapan sistem tersebut.

Untuk mendapatkan gambaran pra kondisi organisasi dilakukan identifikasi dan penelusuran dokumen-dokumen rencana strategis dan laporan kinerja. Pra kondisi lingkungan organisasi terbagi 3 hal, pertama. task environment (tugas pokok dan fungsi), kedua, industry environment (sektor swasta) dan ketiga, macro environment (lingkungan luas meliputi sosial, ekonomi, politik, pengetahuan dan teknologi). Ketiga pra kondisi ini memiliki keterkaitan dalam menjamin kualitas penyelenggaran pelatihan.

Berdasarkan jenis dan karakteristik layanan, BPSDMD Prov. Kalsel tugas pokok dan fungsi dinilai merupakan organisasi penyelenggara pelayanan publik dengan produk layanan berupa jasa pelatihan. Dalam melaksanakan fungsinya, dukungan task environment khususnya SDM sebanyak 104 orang meliputi pejabat struktural, pejabat fungsional widyaiswara, pejabat fungsional umum, dan PTT sebagaimana gambaran tabel 1 dinilai cukup dan mendukung.

Tabel 1. Jumlah aparatur berdasarkan kepangkatan (Posisi Juli 2020)

\begin{tabular}{|c|c|c|c|c|c|c|c|}
\hline \multirow[t]{2}{*}{ No } & \multirow[t]{2}{*}{ Posisi Jabatan } & \multicolumn{4}{|c|}{$\begin{array}{c}\text { Tingkat/Golongan } \\
\text { Kepangkatan }\end{array}$} & \multirow[t]{2}{*}{ JLH } & \multirow[t]{2}{*}{ KET } \\
\hline & & I & II & III & IV & & \\
\hline 1. & Kepala Badan & - & - & - & 1 & 1 & $\mathrm{~S} 2$ \\
\hline 2. & Sekretaris & - & - & - & - & - & - \\
\hline 3. & Kepala Bidang & - & - & - & 3 & 3 & $\mathrm{~S} 2$ \\
\hline 4. & Kepala Sub Bagian & - & - & 2 & - & 2 & $\mathrm{~S} 1 / \mathrm{S} 2$ \\
\hline 5. & Kepala Sub Bidang & - & - & 6 & 2 & 8 & $\mathrm{~S} 1 / \mathrm{S} 2$ \\
\hline 6. & Widyaiswara & - & - & 4 & 14 & 18 & $\mathrm{~S} 2 / \mathrm{S} 3$ \\
\hline 7. & Arsiparis & - & - & 2 & - & 2 & $\mathrm{~S} 1$ \\
\hline 8. & Pranata Komputer & - & 2 & - & - & 2 & D3 \\
\hline 9. & Staf/Fungsional Umum & 3 & 12 & 23 & - & 38 & $\mathrm{~S} 1 / \mathrm{S} 2$ \\
\hline 10. & PTT & - & - & - & - & 30 & - \\
\hline & J U M L A H & 3 & 14 & 37 & 20 & 104 & \\
\hline
\end{tabular}

Sumber: Sub Bagian Kepegawaian BPSDMD 2020

Potensi dan prospek pengembangan kompetensi peserta pelatihan merupakan aspek penting capaian misi organisasi. Capaian dan asal peserta pelatihan hasil olah data dari sumber dokumen Lakip TA 2018 dan TA 2019 sebagaimana tabel 2 menunjukkan potensi dan peluang besar dalam pengembangan kompetensi ke depan. 
Tabel 2. Jenis Pelatihan dan Jumlah Peserta Pelatihan TA 2018

\begin{tabular}{|c|c|c|c|c|}
\hline No & Nama Diklat & $\begin{array}{c}\text { Jumlah } \\
\text { Peserta } \\
\text { (Org) }\end{array}$ & $\begin{array}{c}\text { Jumlah } \\
\text { Peserta } \\
\text { Kompeten } \\
\text { (Org) }\end{array}$ & Asal Peserta \\
\hline 1. & Diklat Kepemimpinan Tk II & 60 & 60 & Seluruh Indonesia \\
\hline 2. & Diklat Kepemimpinan Tk III & 120 & 119 & Prov, Kab/ Kota \\
\hline 3. & Diklat Kepemimpinan Tk IV & 196 & 196 & Prov, Kab/Kota \\
\hline 4. & Diklat Pra Jabatan Gol I dan II & 343 & 343 & Prov, Kab/ Kota \\
\hline 5. & Diklat Prajabatan Gol III & 134 & 134 & Prov, Kab/Kota \\
\hline 6. & Diklat Polisi Pamong Praja & 30 & 30 & Prov, Kab/Kota \\
\hline 7. & P2UPD & 28 & 28 & Prov, Kab/Kota \\
\hline 8. & Diklat Fungsional Pustakawan & 30 & 9 & Prov.Kalsel \\
\hline 9. & $\begin{array}{l}\text { Diklat Fungsional Pengelola } \\
\text { Arsip }\end{array}$ & 30 & 13 & Prov.Kalsel \\
\hline 10. & Diklat Manajemen Kepegawaian & 30 & 30 & Prov.Kalsel \\
\hline 11. & $\begin{array}{l}\text { Diklat Dasar Manajemen } \\
\text { Penanggulangan Bencana }\end{array}$ & 30 & 19 & Prov.Kalsel \\
\hline 12. & Diklat Penyusunan LJKPJ/LPPD & 30 & 30 & Prov.Kalsel \\
\hline 13. & $\begin{array}{l}\text { Diklat Pengadaan Barang dan } \\
\text { Jasa Pemerintah }\end{array}$ & 30 & 30 & Prov.Kalsel \\
\hline 14. & $\begin{array}{l}\text { Diklat Laporan Keuangan } \\
\text { Berbasis Akrual }\end{array}$ & 30 & 30 & Prov.Kalsel \\
\hline 15. & $\begin{array}{l}\text { Diklat Pengelolaan Barang } \\
\text { Daerah }\end{array}$ & 30 & 30 & Prov.Kalsel \\
\hline 16. & Diklat Revolusi Mental & 58 & 58 & Prov.Kalsel \\
\hline & Diklat Penyusunan Renstra & 30 & 30 & Prov.Kalsel \\
\hline & Diklat SPIP & 60 & 60 & Prov.Kalsel \\
\hline & Jumlah & 1299 & 1249 & \\
\hline
\end{tabular}

Sumber : LAKIP 2018

Berdasarkan tabel 1 dan 2, capaian kinerja pelatihan 2018 dibanding 2019 menunjukkan peningkatan kuantitas peserta 104\%, meski jumlah pelatihan menurun dari 18 menjadi 16 pelatihan. Peserta selain aparatur pemerintah provinsi, menggunakan pola kontribusi sesuai Standar Biaya Umum (SBU) masing-masing jenis pelatihan. Dari gambaran di atas, ada peluang dan potensi besar mendesain program pelatihan inovatif dan berskala luas yang dapat diikuti oleh aparatur provinsi atau luar provinsi.

Keterkaitan penyelenggaran pelatihan dengan lingkungan industri (industry environment) dilaksanakan melalui proses seleksi sesuai spesifikasi penyedia untuk penyediaan konsumsi/makanan, kesehatan/obat-obatan, jasa transportasi/travel, perlengkapan peserta, termasuk layanan jasa tenaga listrik, komunikasi dan jaringan internet. Kerjasama dan kolaborasi telah dilaksanakan dan berjalan baik mendukung penyelenggaraan pelatihan.Gambaran akuntabilitas penyelenggaraan pelatihan, memiliki sertifikat akreditasi dan sertifikat mutu meliputi akreditasi A Diklat Prajabatan Golongan I, II dan III, Kepemimpinan Tingkat III dan IV serta rekomendasi PKN II. Akreditasi pelatihan teknis meliputi PBJ dan pelatihan kebencanaan dilevel A dan sertipikat jaminan mutu pelatihan (Certificate of Registration) dari NQA untuk ISO 9001:2008.

Dukungan sarana prasaran pelatihan dinilai memenuhi dengan 2 kampus di $\mathrm{Jl}$. Panglima Batur Timur No.1 A Banjarbaru (2,5 Ha) kapasitas 120 kamar dan Jl. Ambulung Loktabat Banjarbaru (4,5 Ha) kapasitas 120 kamar. Penggunaannya untuk perkantoran, asrama, ruang kelas, ruang makan, aula, laboratorium komputer, perpustakaan, mushola, guest house, lapangan tenis, futsal, fasilitas fitness dan hiburan karaoke. 
Tabel 3. Jenis pelatihan dan jumlah peserta pelatihan TA 2019

\begin{tabular}{|c|c|c|c|c|}
\hline No & Nama Diklat & $\begin{array}{c}\text { Jumlah } \\
\text { Peserta } \\
\text { (Org) }\end{array}$ & $\begin{array}{c}\text { Jumlah } \\
\text { Peserta } \\
\text { Kompeten } \\
\text { (Org) }\end{array}$ & Asal Peserta \\
\hline 1. & Diklat Kepemimpinan Tk II & 53 & 53 & Seluruh Indonesia \\
\hline 2. & Diklat Kepemimpinan Tk III & 120 & 120 & Prov, Kab/ Kota \\
\hline 3. & Diklat Kepemimpinan Tk IV & 160 & 159 & Prov, Kab/ Kota \\
\hline 4. & Diklat Pra Jabatan Gol I dan II & 360 & 360 & Prov, Kab/ Kota \\
\hline 5. & Diklat Prajabatan Gol III & 1.080 & 1.076 & Prov, Kab/ Kota \\
\hline 6. & Orientasi DPRD & 430 & 429 & $\mathrm{Kab} /$ Kota \\
\hline 7. & $\begin{array}{l}\text { Diklat Fungsional Pamong } \\
\text { Praja }\end{array}$ & 19 & 19 & Prov, Kab/ Kota \\
\hline 8. & $\begin{array}{l}\text { Diklat Penyusunan } \\
\text { LJKPJ/LPPD }\end{array}$ & 28 & 27 & Prov.Kalsel \\
\hline 9. & $\begin{array}{l}\text { Diklat Pengadaan Barang dan } \\
\text { Jasa Pemerintah Eselon II }\end{array}$ & 51 & 51 & Prov.Kalsel \\
\hline 10. & $\begin{array}{l}\text { Diklat Dasar Manajemen } \\
\text { Penanggulangan Bencana }\end{array}$ & 30 & 30 & Prov.Kalsel \\
\hline 11. & Diklat Tata Naskah Kedinasan & 30 & 30 & Prov.Kalsel \\
\hline 12. & Diklat Kearsipan & 30 & 30 & Prov.Kalsel \\
\hline 13. & $\begin{array}{l}\text { Diklat Pengadaan Barang dan } \\
\text { Jasa Pemerintah }\end{array}$ & 30 & 30 & Prov.Kalsel \\
\hline 14. & Diklat Penguatan SAKIP & 57 & 57 & Prov.Kalsel \\
\hline 15. & Diklat Penyusunan Renstra & 30 & 30 & Prov.Kalsel \\
\hline & Diklat SPIP & 142 & 142 & Prov.Kalsel \\
\hline & Jumlah & 2.650 & 2.643 & \\
\hline
\end{tabular}

\section{Sumber : LAKIP 2019}

Berdasarkan hasil penelusuran dokumen dan kondisi obyektif pra kondisi organisasi BPSDMD Prov. Kalsel, berbagai aspek meliputi SDM, akreditasi, dukungan lingkungan organisasi serta sarana prasarana dinilai sangat memadai mendukung perubahan sistem pengelolaan keuangan BLUD. Hal ini sejalan dengan pendapat Sutanto (2018) yang menilai bahwa penerapan atau peningkatan status menjadi BLUD melihat faktor kemampuan keuangan, kelengkapan sarana dan prasarana yang dimiliki. Selain kesiapan beberapa aspek di atas menurut Widaningtyas (2018), komitmen internal perlu digalang/ditingkatkan untuk membuat suasana yang mendukung kesiapan penerapan kebijakan BLUD. Secara obyektif perubahan manajemen pengelolaan keuangan mendorong perubahan/transformasi dari konsep "business as usual" atau menjalankan rutinitas menjadi lembaga pelatihan yang berkembang, mandiri dan inovatif.

\section{Kelayakan Penerapan BLUD pada BPSDMD Provinsi Kalimantan Selatan dalam Perspektif Permendagri 79 Tahun 2018}

Perubahan paradigma pengelolaan pemerintah dengan mengemukanya konsep new public manajamen (NPM), mendorong terjadinya perubahan kinerja lembaga penyelenggara pelayanan publik. Pergeseran paradigma ditegaskan artikel Osborne dan Gaebler (1992) mengenai reinventing government. Konsep ini mendorong birokrasi dijalankan dengan konsep korporasi sehingga memperjelas hubungan penyedia layanan dan penerima layanan.

Kebijakan reformasi keuangan mendorong pengelolaan birokrasi ala korporasi dengan mengurangi rantai birokrasi yang menghambat proses pelayanan. Penerapan sistem pengeloaan keuangan melalui BLUD, pengelolaan keuangan yang mandiri dan memiliki fleksibilitas salah satu upaya perbaikan pelayanan. Dalam Permendagri Nomor 79 Tahun 2018 menyebutkan pengertian BLUD "sistem yang diterapkan oleh unit pelaksana teknis dinas/badan daerah dalam memberikan pelayanan kepada masyarakat yang mempunyai 
fleksibilitas dalam pola pengelolaan keuangan sebagai pengecualian dari ketentuan pengelolaan keuangan daerah pada umumnya".

Konsep BLUD dimaknai sebagai lembaga di lingkungan pemerintah daerah yang menyediakan barang atau jasa dengan prinsip efisiensi dan produktifitas tanpa mengutamakan mencari keuntungan. Dana yang dikeluarkan harus berbanding lurus dengan manfaat (produktifitas), dan ukuran kinerja BLUD bukan berapa besar keuntungan (profit) yang di dapat, tetapi ukuran-ukuran lain yang digunakan organisasi nirlaba. Pembahasan mengenai kelayakan penerapan konsep BLUD pada lembaga pelatihan sebagai tujuan kajian, khususnya BPSDMD Prov.Kalsel, dinilai penting dan urgen. Analisis kelayakan terkait pemenuhan/kesesuaian persyaratan sebagaimana regulasi, dengan kondisi, kedudukan dan kinerja eksisting saat ini. Dalam Bab II, Tahapan Penerapan BLUD Peraturan Menteri Dalam Negeri Nomor 79 Tahun 2018 Pasal 29 disebutkan bahwa Unit Pelaksana Teknis Daerah/Badan Daerah yang akan menerapkan BLUD harus memenuhi persyaratan yang meliputi : substantif, teknis dan administratif. Persyaratan substantif meliputi dua persyaratan: (1) syarat terpenuhi apabila tugas dan fungsi UPT dinas/badan daerah bersifat operasional dalam menyelenggarakan layanan umum menghasilkan semi barang/jasa publik; dan (2) layanan umum harus berhubungan dengan layanan umum penyediaan barang dan/atau jasa, layanan kepada masyarakat pengelolaan dana khusus untuk meningkakan ekonomi dan/atau pengeloaan wilayah/kawasan tertentu untuk tujuan meningkatkan perekonomian masyarakat atau layanan umum.

Analisa persyaratan substantif merujuk Peraturan Gubernur Nomor 0137 Tahun 2017 tentang Tugas Pokok, Fungsi dan Uraian BPSDMD Provinsi Kalimantan Selatan dan dokumen rencana strategis, memenuhi karakteristik organisasi penyelenggara pelayanan publik menghasilkan jasa semi publik, jasa pelatihan bagi aparatur. Adanya produk berupa jasa menjadi indikator output layanan publik dan hal ini relevan dan memenuhi persyaratan substantif penerapan BLUD. Mengenai pihak yang memperoleh layanan atau pelanggan, dari gambaran informan berasal instansi layanan kesehatan yang telah menerapkan BLUD, informan RS Moch Ansari Saleh, RSJ Sambang Lihum dan RSUD Ulin memiliki pendapat sama terkait siapa yang mendapat layanan kesehatan. Sebagai penyelenggara pelayanan kesehatan, karakteristik pelanggan jelas, yaitu pasien dan keluarga pasien atau masyarakat umum lainnya yang mendapatkan layanan-layanan kesehatan. Semua pelanggan menerima hak layanan berkualitas dan kewajiban yang harus di penuhi atau di bayarkan sebagai imbalan jasa layanan yang tidak ditanggung pemerintah.

Berdasarkan hasil wawancara, penilaian informan dari Sub Direktorat BLUD Direktorat Jenderal Keuangan Daerah Kementrian Dalam Negeri Republik Indonesia terkait masyarakat dalam konteks pelayanan yang diberikan lembaga pelatihan dimaknai sebagai masyarakat aparatur di lingkungan pemerintah daerah, baik aparatur provinsi, kabupaten atau kota. Urgensi dan penegasan terkait penerapan BLUD "[...] apabila penyelenggaraan pelatihan hanya melayani aparatur yang bekerja di pemerintah provinsi dan dibiayai oleh APBD Provinsi, tidak perlu dibentuk BLUD, namun apabila pelayanan pelatihan menjangkau aparatur pemerintah kabupaten/kota yang mengikuti pelatihan dengan biaya APBD Kabupaten Kota, dapat diterapkan PK BLUD”. Pernyataan ini menegaskan dapat diterapkan BLUD manakala asal peserta tidak hanya dari aparatur provinsi, hal ini sesuai dengan gambaran asal peserta pada uraian terdahulu. Pola kontribusi dari kabupaten/kota merupakan ukuran dapat diterapkannya konsep BLUD. Dengan pola kontribusi, dengan penerapan pengelolaan keuangan yang mandiri dan memiliki fleksibilitas, dana masuk dapat langsung digunakan untuk biaya operasional kegiatan pelatihan, prosedur dapat diperpendek.

Analisa persyaratan teknis Pasal 34 Permendagri Nomor 79 Tahun 2018 menyangkut dua kondisi yang harus dipenuhi dan dinilai relevan, yaitu bahwa persyaratan teknis terpenuhi apabila, pertama, karakteristik tugas dan fungsi Unit Pelaksana Teknis Dinas/Badan daerah dalam memberikan pelayanan lebih layak apabila dikelola dengan 
menerapkan BLUD, sehingga dapat meningkatkan pencapaian target keberhasilan, kedua, berpotensi meningkatkan pelayanan kepada masyarakat dan kinerja keuangan apabila dikelola dengan menerapkan BLUD.

Menyangkut kelayakan karakteristik tugas dan fungsi, bahwa lembaga pelatihan dituntut cepat dan tepat dalam merespon keluhan peserta pelatihan, tidak dapat ditunda, harus segera diatasi agar proses pembelajaran dapat kembali lancar. Ernawati dan Azkha (2018), menyampaikan ketidakefisienan penyediaan dana bahwa realisasi anggaran harus sesuai aliran anggaran kas yang telah disusun dan apabila ada keperluan mendesak sulit di atasi. Kesiapan dan ketersediaan sumber daya khususnya dana menjadi faktor pendukung kualitas pelayanan. Dengan BLUD, yang mandiri dan fleksibel, permasalahan ketersediaan dana dapat diatasi, proses lebih efisien.

Permasalahan keterbatasan anggaran, dengan fleksibilitas BLUD, membuka peluang mendapatkan dana selain APBD provinsi melalui kerjasama dengan pihak lain. Adanya alternatif sumber dana berdampak pada perencanaan program pelatihan yang variatif dan dibutuhkan stakeholder. Implementasi BLUD di lembaga pelatihan BKPSDM Kota Lubuk Linggau, Latkesmas Murnajati Malang dan BPSDM Sumatera Selatan, menunjukkan perkembangan program kegiatan mengalami peningkatan khususnya kuantitas/jumlah dan variasi program kegiatan pelatihan. Sisi pendapatan setelah menerapkan BLUD menunjukkan tren meningkat dari tahun ke tahun. Hal ini sejalan dengan hasil penelitian Rondonuwu (2013), bahwa implementasi kebijakan BLUD di rumah sakit jiwa memberikan dampak positif terhadap kinerja keuangan, kinerja pelayanan dan peningkatan pendapatan dan pembagian jasa pelayanan kepada seluruh karyawan. Berdasarkan gambaran analisa efektifitas dan efisiensi layanan serta kinerja keuangan, BPSDMD Provinsi Kalimantan Selatan di nilai layak dan memenuhi persyaratan teknis penerapan BLUD.

Penerapan BLUD wajib memenuhi 6 persyaratan administratif lampiran usulan meliputi surat pernyataan kesanggupan meningkatkan kinerja berisi pernyataan pimpinan instansi dalam kesanggupan melaksanakan SPM, meningkatkan manfaat dan kinerja bidang keuangan dan non keuangan, serta menerapkan praktek bisnis yang sehat. Dokumen ini dapat di siapkan sesuai format dan ditanda tangani pimpinan instansi.

Dokumen pola tata kelola merupakan dokumen induk BLUD ditetapkan Peraturan Kepala Daerah. Dalam penelusuran data sekunder, dokumen yang relevan dengan dokumen pola tata kelola adalah Peraturan Gubernur Tentang Kedudukan, Susunan Organisasi, Tugas, Fungsi dan Tata Kerja Perangkat Daerah Provinsi Kalimantan Selatan dan Peraturan Gubernur tentang Tugas Pokok, Fungsi dan Uraian Badan Pengembangan Sumber Daya Manusia Daerah Provinsi Kalimantan Selatan. Dokumen tata kelola disesuaikan dengan kewenangan, tugas pokok, fungsi, struktur lembaga, pemenuhan persyaratan dokumen pola tata kelola, khususnya beberapa aspek dapat disusun dan perlu disesuaikan dengan melihat secara obyektif kebutuhan lembaga di masa mendatang sehingga pola tata kelolanya memberikan keleluasan dalam pengembangan BLUD.

Rencana strategis bisnis sebagai dokumen perencanaan lima tahunan dan standar pelayanan minimal BLUD dapat disusun dan dipersiapkan dengan format yang telah di tetapkan. Standar pelayanan minimal, dokumen yang ditetapkan peraturan kepala daerah yang memuat batasan minimal mengenai jenis dan mutu layanan dasar yang harus dipenuhi. Dokumen laporan keuangan pokok disusun sesuai dengan sistem akuntansi yang diterapkan pada pemerintah daerah. Laporan keuangan pokok terdiri dari laporan realisasi anggaran, laporan neraca, laporan operasional, laporan perubahan ekuitas dan laporan catatan atas laporan keuangan. Dokumen dimaksud relevan dengan laporan keuangan lembaga yang disusun setiap tahun sebagai bentuk akuntabilitas pengelolaan keuangan, hanya perlu disesuaikan dengan format laporan keuangan berdasarkan ketentuan persyaratan BLUD. 
Laporan keuangan SKPD sebagai dokumen persyaratan disusun sebagai bentuk akuntabilitas keuangan. Adanya laporan menjadi gambaran akuntabilitas kinerja sebagai perwujudan pelaksanaan tugas dan fungsi instansi. Hasil kajian Tama (2018) mengenai aspek keuangan, bahwa tidak terdapat korelasi antara pelayanan dengan efektifitas dan efisiensi keuangan di rumah sakit, namun kinerja keuangan berkorelasi secara kuat terhadap efektifitas dan efisiensi di rumah sakit.

\section{Akuntablitas Keuangan Tahun Anggaran (TA) 2018}

Anggaran pendapatan dan belanja TA 2018 BPSDMD Provinsi Kalimantan Selatan terdiri atas, anggaran pendapatan sebesar Rp. 14.570.927.585, sedangkan anggaran belanja totalnya (Rp. 37.423.874.912) terbagi menjadi 2, belanja tidak langsung (Rp. 9.562.959.000) dan belanja langsung (Rp. 27.860.915.912). Anggaran belanja langsung TA 2018 digunakan untuk pelaksnaan program dan kegiatan langsung sebagaimana rincian tabel berikut:

Tabel 4. Program Kegiatan dan Alokasi Anggaran TA 2018

\begin{tabular}{llr}
\hline \multicolumn{1}{c}{ No } & \multicolumn{1}{c}{ Program dan Kegiatan } & Pagu Anggaran \\
\hline 1. & Program Pelayanan Administrasi Perkantoran & 7.591 .758 .312 \\
\hline 2. & Program Peningkatan Sarana dan Prasarana Aparatur & 3.923 .316 .400 \\
\hline 3. & $\begin{array}{l}\text { Program Pengembangan Sistem Perencanaan, Pelaporan, Capaian } \\
\text { Kinerja dan Keuangan }\end{array}$ & 120.050 .000 \\
\hline 4. & Program Peningkatan Kapasitas Pelayanan Publik & 700.864 .000 \\
\hline 5. & Program Peningkatan Kapasitas dan Kualitas Aparatur & 37.050 .000 \\
\hline 6. & Program Pendidikan Kedinasan & 15.487 .877 .200 \\
\hline & Jumlah & 27.860 .915 .912 \\
\hline
\end{tabular}

Sumber : Laporan Akuntabilitas Kinerja BPSDMD Prov Kalsel 2018

Program dan kegiatan direncanakan secara optimal dilaksanakan dengan target realisasi fisik dan keuangan terukur dan tepat waktu memperhatikan efisiensi dan efektifitas penggunaan anggaran. Gambaran realisasi anggaran serta persentase capaian BPSDMD Provinsi Kalimantan Selatan pada TA 2018 secara global dapat dilihat pada tabel 5 berikut :

Tabel 5. Realisasi Penggunaan Anggaran TA 2018

\begin{tabular}{lcrc}
\hline \multicolumn{1}{c}{ Uraian } & Anggaran & \multicolumn{1}{c}{ Realisasi } & Persentase (\%) \\
\hline Pendapatan Daerah & 14.570 .927 .585 & 9.088 .578 .000 & 62.37 \\
\hline Belanja Daerah & 37.423 .874 .912 & 32.216 .137 .389 & 86.08 \\
\hline Belanja tidak Langsung & 9.562 .959 .000 & 8.814 .355 .225 & 92.17 \\
\hline Belanja Langsung & 27.860 .915 .912 & 23.401 .782 .164 & 84.00 \\
\hline
\end{tabular}

Sumber : Laporan Akuntabilitas Kinerja BPSDMD Prov Kalsel 2018

Berdasarkan tabel 5, komponen pendapatan tidak memenuhi target, tetapi disisi belanja terdapat efisiensi penggunaan dana sebesar 13,92 persen atau sebesar Rp5.207.737.523 yang berasal dari belanja langsung, maupun tidak langsung dari adanya kegiatan yang tidak terlaksana.

Akuntabilitas Keuangan TA 2019: Target pendapatan meningkat 52,65 persen menjadi Rp22.243.210.000. Anggaran TA 2019 meningkat dibanding TA 2018 meliputi belanja langsung ( Rp8.938.164.000) dan belanja tidak langsung (Rp39.834.438.590). Belanja langsung di alokasikan untuk mendukung program kegiatan sebagaimana tabel 6 .

Program dan kegiatan yang direncanakan secara optimal dilaksanakan dengan target realisasi fisik dan keuangan secara terukur dan tepat waktu dengan memperhatikan efisiensi dan efektifitas penggunaan anggaran. Gambaran realisasi anggaran serta prosentasi capaian dari BPSDMD Provinsi Kalimantan Selatan pada TA 2019 secara global dapat dilihat pada tabel 7. 
Tabel 6. Program Kegiatan dan Alokasi Anggaran TA 2019

\begin{tabular}{|c|c|c|}
\hline No & Program dan Kegiatan & Anggaran \\
\hline 1. & Program Pelayanan Administrasi Perkantoran & 4.466 .435 .000 \\
\hline 2. & Program Peningkatan Sarana dan Prasarana Aparatur & 7.241 .540 .140 \\
\hline 3. & $\begin{array}{l}\text { Program Pengembangan Sistem Perencanaan, } \\
\text { Pelaporan, Capaian KInerja dan Keuangan }\end{array}$ & 196.000 .000 \\
\hline 4. & $\begin{array}{llll}\text { Program Peningkatan Kapasitas dan Kualitas } \\
\text { Aparatur }\end{array}$ & 581.600 .000 \\
\hline 5. & Program Pendidikan Kedinasan & 27.348 .863 .450 \\
\hline & Jumlah & 39.834 .438 .590 \\
\hline
\end{tabular}

Sumber : Laporan Akuntabilitas Kinerja BPSDMD Prov Kalsel 2019

Tabel 7. Realisasi Penggunaan Anggaran TA 2019

\begin{tabular}{lrrc}
\hline \multicolumn{1}{c}{ Uraian } & \multicolumn{1}{c}{ Anggaran } & \multicolumn{1}{c}{ Realisasi } & Persentase (\%) \\
\hline Pendapatan Daerah & 22.243 .210 .000 & 20.360 .132 .000 & 91.53 \\
\hline Belanja Daerah & 48.772 .602 .590 & 41.200 .314 .010 & 84.47 \\
\hline Belanja tidak Langsung & 8.938 .164 .000 & 8.574 .328 .211 & 95.93 \\
\hline Belanja Langsung & 39.834 .438 .590 & 32.625 .985 .799 & 81.90 \\
\hline
\end{tabular}

Sumber : Laporan Akuntabilitas Kinerja BPSDMD Prov Kalsel 2019

Berdasarkan tabel 7, capaian pendapatan belum memenuhi target namun dinilai tinggi sebesar 91,53\%. Pelaksanaan Diklatpim Tk II dan uji kompetensi pola kontribusi dari kabupaten/kota tidak terpenuhi. Belanja realisasi mencapai 84,47 persen. Gambaran perkembangan pendapatan dan belanja dalam 2 tahun (2018 dan 2019) menunjukkan tren meningkat. Potensi peningkatan pendapatan dapat digali dari setoran atau kontribusi peserta Latsar CPNS, Diklat Kepemimpinan Tk III dan TK IV, Pelatihan Kepemimpinan Nasional (PKN II) dan uji kompetensi jabatan fungsional dan pengembangan pelatihan teknis unggulan dan dibutuhkan para stakeholder. Dokumen terakhir persyaratan administrasi adalah laporan audit terakhir oleh pemeriksa eksternal pemerintah sebelum unit kerja direkomendasikan menerapkan BLUD. Dalam hal audit terakhir belum tersedia, pimpinan unit kerja pengusul dapat membuat surat pernyataan bersedia di audit oleh pemeriksa eksternal pemerintah sesuai dengan ketentuan perundang-undangan.

Berdasarkan hasil analisa prakondisi dan pemenuhan persyaratan substantif, teknis dan administratif menunjukkan peluang BPSDM Prov.Kalsel menerapkan BLUD sangat besar. Regulasi mengatur kemandirian dan fleksibiltas sistem keuangan membuka peluang sumber pembiayaan dari berbagai sumber. Permasalahan anggaran terbatas dapat diatasi sehingga pengembangan kuantitas dan jenis pelatihan dapat maksimal dan tentunya akan berdampak meningkatnya pendapatan yang berujung pada perbaikan kualitas pelayanan dan kesejahteraan karyawan. Tantangan penerapan BLUD yang utama adalah komitmen untuk melakukan perubahan dan merubah mindset karyawan untuk berjiwa kewirausaaan serta kemampuan untuk menciptakan branding sebagai lembaga pelatihan berkualitas dan dipercaya oleh stakeholder. 
Tabel 8. Gambaran Pemenuhan Persyaratan Penerapan BLUD Berdasarkan Permendagri 79 Tahun 2018 tentang BLUD

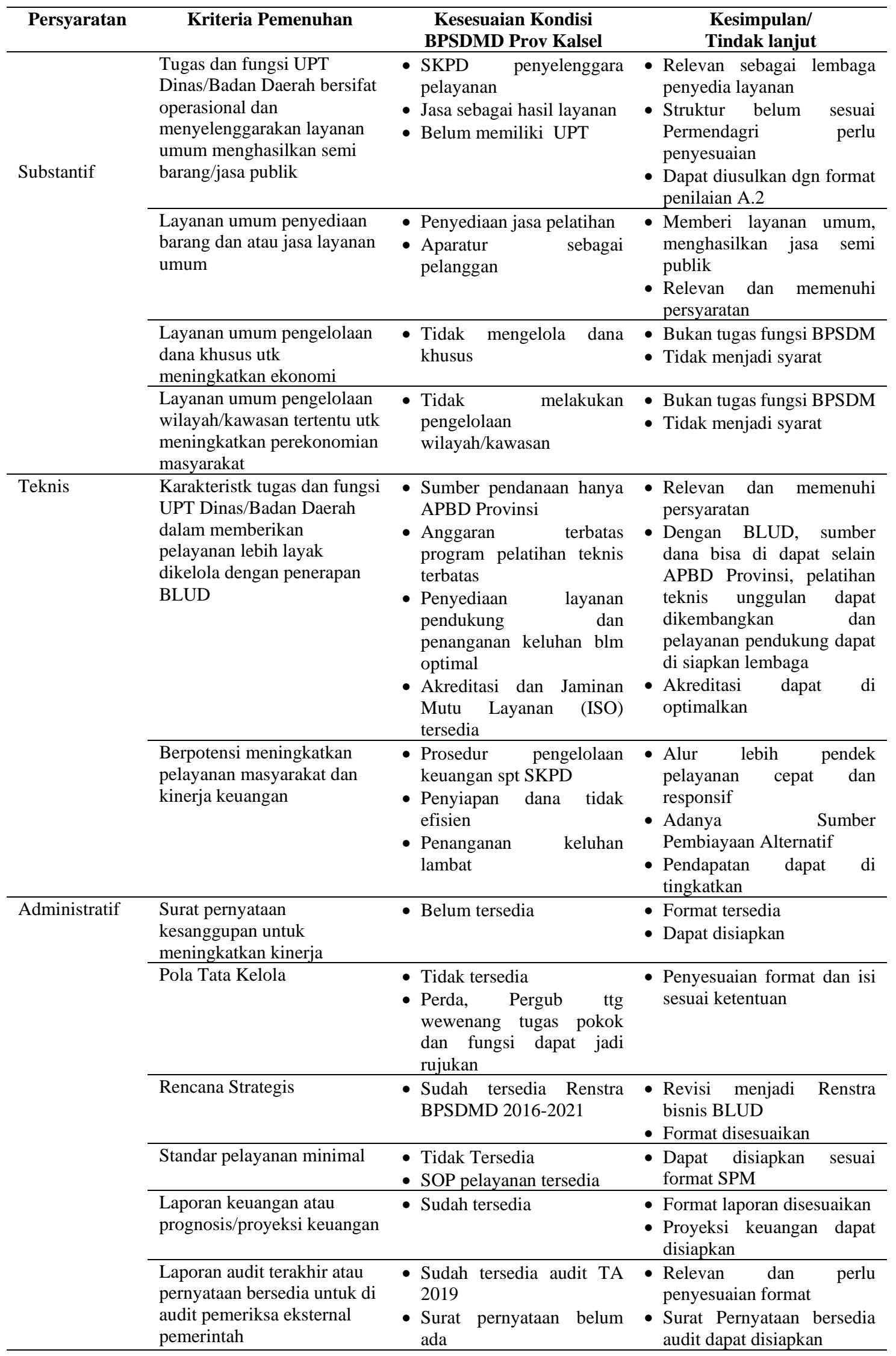




\section{SIMPULAN DAN REKOMENDASI}

\section{Simpulan}

Berdasarkan uraian pembahasan hasil kajian dapat ditarik kesimpulan: (1) prakondisi BPSDMD Provinsi Kalsel menunjukkan indikasi positif mendukung penerapan konsep BLUD. Kesiapan SDM pengelola dan potensi peserta pelatihan, adanya akreditasi, jaminan mutu penyelenggaraan pelatihan, dukungan swasta dan ketersediaan sarana prasarana pelatihan dinilai relevan dan mendukung pengembangan kompetensi ASN dengan menerapkan sistem BLUD yang mandiri dan memiliki fleksibilitas; dan (2) berdasarkan ketentuan persyaratan substantif dan teknis, BPSDMD Provinsi Kalimantan Selatan secara obyektif dinilai sesuai/relevan dengan tugas pokok dan fungsinya menyelenggarakan layanan umum dan menghasilkan jasa semi publik. Lembaga pelatihan dinilai lebih layak dan mampu meningkatkan kinerja keuangan apabila menerapkan sistem BLUD. Keterbatasan anggaran dapat diatasi dengan alternatif sumber pendanaan dan proses penyiapan dana yang lebih cepat, fleksibel dan mandiri. Persyaratan administratif kelengkapan usulan pembentukan BLUD dapat disusun dan disiapkan sesuai menurut format yang ditetapkan.

\section{Rekomendasi}

Berdasarkan hasil kajian direkomendasikan agar disiapkan keputusan tentang Tim Pembentukan BLUD dengan tugas melakukan kordinasi, komunikasi dengan SKPD terkait dan menyiapkan dokumen kelengkapan persyaratan pembentukan BLUD serta melengkapi kajian dari aspek kelembagaan.

\section{UCAPAN TERIMA KASIH}

Ucapan terima kasih kepada pimpinan beserta jajaran atas dukungan dan partisipasi pelaksanaan kajian, pimpinan dan pejabat SKPD yang menjadi narasumber/informan atas informasi dan kesempatan berbagi pengalaman penerapan konsep BLUD di instansi masing-masing.

\section{DAFTAR PUSTAKA}

Draft, Richard L. 2012. New Era of Management. Jakarta: Salemba.

Ernawati, Ch Tuty, and Nizwardi Azkha. April-September 2018. "Studi Implementasi BLUD di UPTD Balai Kesehatan Idera Masyarakat Provinsi Sumatera Barat Tahun 2016." Jurnal Kesehatan Masyarakat Andalas Vol.12 No.2 67-76.

Fahmi, Indra. 2014. "Kajian Pembentukan Badan Layanan Umum Daerah." Jurnal Ilmiah Ekonomi, Koperasi, dan Kewirausahaan Vol. IV No. 1, ISSN 2086-3306.

Lukman, Mediya. 2013. Badan Layanan Umum dari Birokrasi Menuju Korporasi. Jakarta: PT. Bumi Aksara.

Miles, Matthew B, and A Michael Huberman. 2005. Qualitative Data Analysis (terjemahan). Jakarta: UI Press.

Osborne, David, and Peter Plastrik. 1997. Banishing Bureaucracy: The five Strategis for Reinventing Government. Jakarta: PPM.

Osborne, David, and Ted Gaebler. 1992. Reiventing Government: How The Enterpreneurial Spirit is Transforming The Public Sector. Jakarta: Pustaka Binaman Pressindo.

Pandriadi, Angka Wijaya, and Mas Amah. Juli-Des 2017. "Penerapan BLUD KPHP: Akankah Menuju Pengelolaan Hutan Yang Transparan, Akuntabel dan Partisipatif." Jurnal JEMASI Vol. 13 No. 2 135-154. 
Pemerintah Provinsi Kalimantan Selatan. 2018. "Laporan Akuntabilitas Kinerja Pemerintah (LAKIP) BPSDMD Provinsi Kalimantan Selatan TA 2018 dan TA 2019". Banjarbaru

Pemerintah Provinsi Kalimantan Selatan. 2017. Peraturan Gubernur Nomor 0137 Tahun 2017 tentang Tugas Pokok, Fungsi dan Uraian Badan Pengembangan Sumber Daya Manusia Daerah Provinsi Kalimantan Selatan.

Pemerintah Provinsi Kalimantan Selatan. 2016. Rencana Strategis Badan Pengembangan Sumber Daya Manusia Daerah Provinsi Kalimantan Selatan 2016-2021

Pemerintah Republik Indonesia. 2014. Undang-Undang Nomor 5 Tahun 2014 Tentang Aparatur Sipil Negara. Lembaran Negara Republik Indonesia Tahun 2014 Nomor 6. Jakarta.

Robbin, Stephen P. 2006. Prilaku Organisasi”. Terjemahan Benyamin Molan. Jakarta: Kelompok Grandia.

Rondonuwu, Julastri, and Laksono Trisnantoro. 2013. "Manajemen Perubahan Di Lembaga Pemerintah : Studi Kasus Implementasi Kebijakan Pelaksanaan PPK BLUD Di Rumah Sakit Jiwa Provinsi NTB"." Jurnal Kebijakan Kesehatan Indonesia Vol. 02 163-170.

Sutanto, Slamet Hari. Desember 2018. "Posisi Strategis dan Arah Pengembangan Unit Pelaksana Teknis Dinas (UPTD) Menjadi Badan Layanan Umum Daerah (BLUD) di Pemerintah Provinsi Jawa Timur"." Jurnal Analisis Kebijakan dan Pelayanan Publik Vol. 4 No.2 e-ISSN: 2527-6476.

Tama, Annafi Indra. 2018. "Evaluasi Kinerja Pelayanan dan Keuangan RSUD Yang Menerapkan Pola Pengelolaan Keuangan BLUD”." Jurnal PETA Vol. 3 No.2 1125.

Tim BLUD Syncore. 2019. Petunjuk Teknis Pola Pengelolaan BLUD (PPK-BLUD). Yogyakarta: PT. Syncore Indonesia.

Tim BLUD Syncore. 2020. Pengantar BLUD. Yogyakarta: PT. Syncore Indonesia.

Trianasari, Ely, and Muhammad Syafie Idrus. 2011. "Evaluasi Strategi RSUD DR. Syaiful Anwar (RSSA) Malang Sebelum dan Sesudah Badan Layanan Umum Daerah (BLUD) ." Jurnal Bisnis \& Akuntansi Vol. III No. 1, P-ISSN:2338 9583 E-ISSN: 2356-2919.

Widyaningtyas, Endah. Maret 2018. "Kesiapan Tata Kelola Puskesmas Menjadi Badan Layanan Umum Daerah (BLUD)." Jurnal Managemen Informasi Kesehatan Indonesia Vol. 6 No. 1. 
JURNAL Kebijakan Pembangunan Volume 16 Nomor 1 Juni 2021: 29 - 41 